\title{
Folkpension och åldringsvård - om svensk socialpolitik 1903-1950
}

PER GUNNAR EDEBALK

Offentlig socialpolitik för åldringar i Sverige tillhörde den kommunala fattigvården i början av 1900-talet. Efter andra världskriget hade socialpolitiken blivit generell med folkpension och ålderdomshem. Vägen dit kan förstås med hänvisning till förändringar $i$ och av Sveriges agrara struktur, ett ofta förbisett perspektiv.

\section{Inledning}

Vid tiden för bildandet av Centralförbundet för Socialt Arbete, CSA, 1903 var det vanligt att åldringar i behov av försörnning eller omsorg togs om hand av sina barn. Ett sådant arrangemang byggde på lag och tradition. De åldringar som saknade anförvanter eller egna medel hade att förlita sig på den kommunala fattigvården och 1871 års fattigvårdsförordning. Det var oklart om förordningen överhuvudtaget gav den enskilde rätt till understöd. Någon besvärsrätt för den enskilde existerade inte, fattigvården hade husbonde- och målsmansrätt över understödstagarna och någon direkt statlig kontroll över verksamheten fanns inte

Per Gunnar Edebalk är professor i socialt arbete vid Lunds universitet.
(Edebalk, 1991). Missförhållandena inom fattigvården var uppenbara. Ett halvt sekel senare hade beslut tagits att alla åldringar skulle ha rätt till pension och åldringsvård. Åldringarna hade då utmönstrats ur fattigvården och fått en fullvärdig plats i det svenska folkhemmet.

Syftet med denna artikel är att översiktligt beskriva utvecklingen från fattigvård till en generell socialpolitik för åldringar. En sådan utveckling kan beskrivas och analyseras utifrån en rad olika teoretiska perspektiv (se t.ex. Heclo, 1974, Orloff, 1993, Palme 1990, Salminen, 1993). Ofta relateras socialpolitikens utveckling till industrialiseringen och till arbetarrörelsens växande politiska resurser. Man kan emellertid knappast förstå utvecklingen av socialpolitiska insatser för de äldre 
under första halvan av 1900-talet om man inte också beaktar landsbygden. År 1900 bodde en stor majoritet av befolkningen på landsbygden. Flyttningen från landsbygd till tätorter var påtaglig, men ännu så sent som 1930 bodde något fler på landsbygden än i tätorter. Kring mitten av 1930-talet är utflyttningen från landsbygden stark och landsbygden som en bas för socialpolitikens utformning reduceras (SOU 1938:15, SOU 1945:53). Vi skall i denna översikt som främsta bakgrundsfaktor använda den agrara sektorn. Denna var dels skapare av vad som uppfattades som "sociala problem", dels en politisk faktor. Förändringar i och av den agrara sektorn är nära lierade med de ekonomiska, politiska och sociala förändringar som skedde i Sverige.

\section{Åldringsfrågan omkring år 1900}

I spåren av industrialiseringen och därav genomgripande samhällsförändringar hade åldringsfrågan kring förra sekelskiftet kommit upp på den politiska dagordningen i många länder (Orloff, 1993). Pensionsfrågan hade i Sverige fått sin första politiska aktualitet genom liberalen Adolf Hedins bekanta riksdagsmotion 1884 (motion AK 1884:11). Denna i sin tur var inspirerad av det arbetareförsäkringsprogram som var på väg i Tyskland och bar Bismarcks signum. Två statliga utredningar härefter, arbetareförsäkringskommittén och nya arbetareförsäkringskommittén, behandlade pensionsfrågan men något positivt resultat hade inte nåtts före sekelskiftet. Som en reaktion på uteblivna statliga insatser hade friherren G. A. Raab påbörjat ett privat ini- tiativ för att få en lösning av pensionsfrågan till stånd.

Kring sekelskiftet bodde närmare 70 procent av befolkningen på den egentliga landsbygden. Inkluderas även tätorter på landsbygden närmar sig siffran 80 procent. Totalt fanns mer än 2400 kommuner, de flesta mycket små. Den svenska fattigvården var en primärkommunal angelägenhet och kommunerna hade stor frihet att själva utforma sin fattigvård. Förhållandena, eller rättare missförhållandena, inom fattigvården, började alltmer uppmärksammas kring eller strax efter sekelskiftet (Edebalk, 1991). I och för sig hade fattigvårdsfrågan funnits med i diskussionerna alltsedan Hedins motion. Med socialförsäkringar avsåg reformivrarna bl.a. att minska den enskildes fattigvårdsberoende och kommunernas utgifter. Den kommunalfinansiella aspekten var mycket viktig. Sverige hade (jämte Norge) den högsta andelen åldringar bland någorlunda jämförbara länder och andelen åldringar hade ökat kraftigt; Procentandelen äldre $(65+)$ av befolkningen ökade från 4,8 år 1850 till 8,4 år 1900. Bl.a. minskad barnadödlighet i början av 1800-talet och emigrationen i slutet av århundradet ligger bakom denna utveckling. En jämförelse med andra länder visar att den svenska åldersstrukturen var unik. Per 1000 personer i åldern 20-65 år fanns vid seklets början 168 personer som var 65 år eller äldre i Sverige (Ålderdomsförsäkringskommittén, 1912). Motsvarande siffra för Nordamerika, England, Ryssland, Tyskland och Österrike låg mellan 79 och 97. Sverige, som var ett förhållandevis fattigt land hade alltså, relativt sett, ungefär dubbelt så många 65-åringar och äldre än dessa 
länder; jämfört med Danmark är antalet för Sverige ungefär 25 procent högre. Fattigvården finansierades med lokala skatter och för många småkommuner på landsbygden var fattigvårdsutgifterna ytterst betungande och på många håll wrent af olidligt tryckande» enligt riksdagens uppfattning (Riksdagens skrivelse 1905:131). Det var bl.a. detta som i mångt och mycket bidrog till missförhållandena inom den kommunala fattigvården. Men det var också detta man sökte komma till rätta med genom att införa statliga pensioner.

För de "fattighjon" som var vårdbehövande erbjöds, speciellt på landsbygden, fyra understödsformer: Utackordering (som visade sina sämsta sidor när den gamle inte längre orkade delta i det dagliga arbetet), bortauktionering (där den som krävde lägst ersättning från kommunen, d.v.s. ofta andra fattiga, blev "vårdgivare «), rotegång (där de vårdbehövande hade att ständigt flytta mellan rotens medlemmar) samt anstalter (fattigstugor, fattighus och fattiggårdar i vilka olika slags understödstagare blandades: gamla och orkeslösa, kroniskt sjuka, sinnessjuka, föräldralösa barn, alkoholister etc.). Det fanns en tydlig tendens beträffande understödsformerna: anstalterna höll på att få en växande betydelse. I storstäderna hade man börjat bygga jättelika anstalter med plats för över tusen intagna och därmed med möjlighet till differentiering.

Trots uppenbara missförhållanden inom wåldringsvården" fanns endast ett svagt politiskt intresse att reformera fattigvården. Det förekom enstaka riksdagsmotioner som tog upp diverse missförhållanden som t.ex. bortauktioneringen och den ojämna kommunala fattigvårdsbördan (Edebalk, 1991). Det var partiella reformer som påyrkades, men resultatlöst.

Kring sekelskiftet fanns det en rad organisationer och rörelser, som drev olika sociala frågor. Två viktiga exempel är fackföreningsrörelsen och nykterhetsrörelsen. Någon motsvarande organisation som drev fattigvårdsfrågan fanns inte. Strax efter sekelskiftet kom det s.k. "fattigvårdsfolket» att lägga beslag på fattigvårdsfrågan (Lundquist, 1997). Till gruppen räknades några tongivande och ledande personer inom CSA. Till CSA överlämnades år 1904 en stor privat donation, som skulle användas för en utredning av fattigvårdsfrågan. CSA tillsatte en kommitté bestående av G.H. von Koch, Ebba Pauli, Albin Lindblom och Jacob Pettersson. Kommittén ägnade två intensiva år till studiet av fattigvården $\mathrm{i}$ Sverige. Erfarenheter och rön publicerades i skriftserien "Fattigvård och folkförsäkringw. Innan ett slutligt reformförslag lades fram arrangerade kommittén en fattigvårdskongress i Stockholm i oktober 1906.

\section{Fattigvårdkongressen}

Kongressen för fattigvård och folkförsäkring samlade inte mindre än 936 deltagare (Palmstierna, 1907). Den representerade startskottet för en socialpolitisk islossning i Sverige. Det var exempelvis på kongressen som frågan om en statlig arbetslöshetsförsäkring gjorde insteg i den politiska debatten. Kongressen antog här en skrivelse till regeringen med hemställan om en utredning.

Pensionsfrågan fanns, givetvis, också på dagordningen. Kongressen beslutade 
uttala att den ville »lägga statsmakterna på hjärtat att med det första söka åstadkomma en pensionering eller försäkring af mindre bemedlade $i$ vårt land $i$ tidsenlig, effektiv och efter landets tillgångar lämpad form" (Palmstierna, 1907 sid. 269-70). En stor del av kongressen ägnades åt fattigvårdsfrågan och kongressen uttalade sig kraftfullt för en fullständig revision av fattigvårdslagstiftningen. Vid kongressen bildades Svenska Fattigvårdsförbundet, som bl.a. fick som syfte att verka för en reform. CSAs fattigvårdskommitté kom i sin helhet att ingå i förbundets arbetsutskott med G.H. von Koch som ordförande och primus motor.

Fattigvårdsfolkets utredande sedan 1904 resulterade 1907 i betänkandet »Reformlinjer för svensk fattigvårdslagstiftningu. Här, liksom i föredrag och inlägg under kongressen, framträder tydligt deras socialpolitiska ideologi (se också t.ex. Lundqvist, 1997 och Sjögren, 1997). Att avskaffa fattigdom sågs ytterst som en folkuppfostringsfråga. Detta innebar t.ex. att schablonunderstöd utan motprestation inte skulle få förekomma inom socialpolitiken. En implikation härav var att socialförsäkringar, som ju bl.a. hade som syfte att reducera fattigvårdsutgifter, skulle byggas på en strikt försäkringsmässig grund. För fattigvården, och vi håller oss här till den del som är relevant för åldringar, borde en reformering bl.a. leda till att individen får en tydlig rätt till fattigvård. Fattigvårdens former borde likaledes vara tydliga och rotegång och bortauktionering skulle förbjudas. Husbonderätten föreslogs eliminerad och en statlig fattigvårdsinspektör skulle tillsättas. En rejäl upprustning borde ske beträffande anstaltsvården och den s.k. klientelblandningen skulle upphöra. Detta föreslogs bl.a. ske genom att landstingen skulle åläggas att bereda anstaltsvård för sinnessjuka och kroniskt sjuka. Ett par år senare klarnar begreppen: åldringsvård skulle äga rum $\mathrm{i}$ "hemlika» ålderdomshem (Edebalk, 1991).

Fattigvårdskongressen representerade en kraftfull socialpolitisk opinion bl.a. för en reformering av försörjnings- och vårdformer för de äldre. Enligt kongressens krav tillsattes 1907 två stora statliga utredningar. Den ena kommittén skulle utreda en reformering av fattigvårdslagstiftningen. Tre av åtta ledamöter representerade fattigvårdsfolket. Ordförande blev Johan Widén, som var ordförande i Fattigvårdsförbundet och som varit ordförande under fattigvårdskongressen. Den andra kommittén skulle utreda ålderdomsförsäkring. Professorn och socialförsäkringsexperten Anders Lindstedt utsågs som ordförande och bl.a. Hjalmar Branting som ledamot. G.H. von Koch hade under fattigvårdskongressen hävdat watt fattigvård och folkförsäkring måste finnas sida vid sida» och att därför borde "bärarna af dessa båda rörelser från första stund samverka med hvarandra" (Palmstierna, 1907, sid 16). Det uppenbara sambandet mellan pensioner och fattigvård borde alltså leda till någon form av samarbete mellan kommittéerna. Så blev emellertid inte fallet. Ej heller ingick någon representant för fattigvårdsfolket, ens om vi tänjer på begreppet, i ålderdomsförsäkringskommittén. En moderniserad fattigvård, inkluderande en reformerad åldringsvård, var vid den här tiden inte någon högprioriterad politisk fråga. Den frågan kunde fattigvårdsfolket ta hand om. 


\section{Den allmänna pensionsförsäkringen 1913}

År 1913 beslutade den svenska riksdagen att införa en allmän pensionsförsäkring, världens första universella socialförsäkring (Elmér, 1960, Heclo, 1974). Pensionsförsäkringsfrågan hade, som tidigare nämnts, på allvar aktualiserats i riksdagen redan år 1884 av Adolf Hedin. 20 år efter Hedins motion, efter det att två olika offentliga utredningar behandlat frågan och efter ett par regeringsinitiativ, förblev pensionsfrågan olöst. I början av 1900-talet kom pensionsfrågan på nytt upp på den politiska dagordningen.

År 1905 väcktes i riksdagen olika motioner med krav på förnyad utredning. Inför riksdagsvalet 1905 togs pensionsfrågan upp i liberalernas och socialdemokraternas valmanifest och inför 1908 års val även i de konservativas (Håkansson, 1959). Friherre G. A. Raab, som drivit sin uppmärksammade privatfinansierade kampanj för ålderspensioner sedan 1896, presenterade ett utarbetat pensionsförslag 1906. Senare samma år behandlades frågan på fattigvårdskongressen och i slutet av år 1907 tillsatte den då konservativa regeringen den s.k. ålderdomsförsäkringskommittén. Kommittén avlämnade ett betänkande i slutet av år 1912 (Ålderdomsförsäkringskommittén, 1912) och efter en snabb regeringsoch riksdagsbehandling togs det slutgiltiga beslutet i maj 1913 av en i stort sett enig riksdag (Proposition 1913:126).

Den allmänna pensionsförsäkringen omfattade, i allt väsentligt, hela folket. Pensionen skulle utgå till den som var oförmögen till arbete p.g.a. invaliditet eller som uppnått 67 års ålder. Försäkringen bestod av två delar:

1. En avgiftspension, finansierad av egenavgifter som utgick efter taxerad inkomst. Pensionens storlek var relaterad till värdet av inbetalda avgifter. En sådan pension skulle emellertid få en socialt acceptabel effekt först efter flera år då tillräckligt mycket avgifter erlagts.

2. En skattefinansierad inkomstprövad tilläggspension, som skulle utgå till dem med ingen eller liten avgiftspension. Tillläggspensionen hade till syfte att snabbt få bort invalider och åldringar från fattigvården.

Både avgiftspensionen och tilläggspensionen var högre för män än för kvinnor. Detta motiverades med att kvinnor hade en genomsnittligt längre livstid och högre invaliditetsfrekvens jämfört med män (Elmér, 1960). Ett inte orimligt antagande är att särbehandlingen av kvinnor sammanhänger med att den allmänna rösträtten endast omfattade män vid den här tiden.

Hur kan man förstå varför Sverige var först $i$ världen med en universell pensionslösning och varför modellen med avgiftspension valdes? I de diskussioner och förslag som funnits med i bilden sedan 1880-talet kan man urskilja fem alternativa huvudmodeller (Edebalk, 1996). Två av dessa hade en svag uppbackning och kan betraktas som orealistiska. Den ena var en statssubventionerad frivillig försäkring, som fanns bl.a. i Belgien, Frankrike och Italien. Erfarenheten hade visat att en frivillig försäkring får en obetydlig omfattning och att det knappast var de mest behövande som försäkrade sig. En pensionsförsäkring måste därför vara obligatorisk. Den 
andra omöjliga modellen var en universell skattefinansierad enhetspension (alltså motsvarande det som senare kom att kallas folkpension). Med någorlunda hyggliga ersättningsnivåer fanns inte finansiella förutsättningar för en sådan lösning och någon sådan modell fanns inte i något land vid den här tiden. Det återstod således tre huvudalternativ, som kan ses som realistiska:

1. Den tyska modellen, som införts 1889, ingick i Bismarcks arbetarförsäkringar. Försäkringen omfattade arbetare och den finansierades (med visst statligt stöd) genom arbetsgivaravgifter och egenavgifter. Avgifterna var relaterade till lönen och pensionen till värdet av inbetalda avgifter. Den tyska modellen var försäkringsmässig.

2. Den danska modellen från 1891 var ett försörjningssystem med schabloniserade ersättningar utan fattigvårdskaraktär. Systemet administrerades av kommunerna och det finansierades av staten och kommunerna med hälften var. Pension utgick efter behovsprövning till "värdiga» åldringar. En variant av den danska modellen beslutades 1908 i Storbritannien, där pensionerna blev skattefinansierade och inkomstprövade.

3. Raabs modell, d.v.s. det förslag han presenterade 1906, omfattade i princip hela befolkningen. Pensionen var inkomstprövad och finansierades med en obligatorisk enhetlig egenavgift (samma avgift för alla).

Då det gäller framväxten av socialförsäkringar finns många exempel på möjliga "drivkrafter». Under de 30 år som förflutit sedan Hedin initierade pensionsfrågan, hade Sverige genomgått en snabb ekonomisk utveckling. Den industriella tillväxten var stark, särskilt från 1890-talet. Industriarbetarna hade organiserat sig fackligt och politiskt och krävde bl.a. sociala rättigheter i stället för den förnedrande kommunala fattigvården. Den ekonomiska utvecklingen följdes av sociala och politiska förändringar och 1911 debuterade allmän rösträtt för män. Den här i korthet beskrivna utvecklingen kan bidra till att förklara att ett pensionssystem infördes som ett försörjningsalternativ till den kommunala fattigvården. Men varför valdes en modell med universell avgiftspension och inte någon av de ovan angivna modellerna?

\section{Varför blev pensionsförsäkringen allmän?}

Då det gäller påverkan på tidiga socialpolitiska beslut hänvisas ofta till Sveriges agrara struktur (se t ex Baldwin, 1990, Elmér 1960, Olofsson 1993). De svenska bönderna hade ett starkt politiskt inflytande; enligt en studie av riksdagens andra kammare för år 1912 bodde 67 procent av ledamöterna på landsbygden och 45 procent var jordbrukare (Sköld \& Halvarson, 1966). Bönderna hade intresse av att minska landsbygdskommunernas fattigvårdsbörda men var också ovilliga att betala arbetsgivaravgifter för sina anställdas pensionering. Viktigt här är också att det socialdemokratiska partiet önskade bredda sin väljarbas och appellera till landsbygdens "småfolk". Många äldre på landsbygden skulle inte kunna omfattas i en Bismarck-modell. Landsbygdsintressena kunde följaktligen inte förorda den tyska lösningen. Då det 
gäller möjligheten att finansiera ålderspensioner fanns andra avgörande skillnader mellan Sverige och Tyskland. Bismarck hade först sökt införa en skattefinansierad arbetarförsäkring i Tyskland (Toft, 1996), men de politiskt starka delstaterna vägrade acceptera detta. Enda möjligheten blev då att ålägga arbetsgivarna och arbetarna att själva betala avgifter. Till skillnad från Tyskland hade Sverige en förhållandevis stark centralmakt, där bönderna hade ett stort politiskt inflytande.

En dansk modell eller en Raab-modell skulle emellertid kunna vara möjliga eftersom dessa är behovs - eller inkomstprövade, varigenom de omfattar alla fattiga. Man måste därför gå ett steg vidare för att förstå varför alternativet med en universell avgiftspension valdes i stället för dessa modeller.

En sannolikt viktig faktor var den speciella demografiska situationen i Sverige. Den demografiska utvecklingen i kombination med industrialisering och urbanisering skapade, som tidigare nämnts, allvarliga finansiella problem för många landsbygdskommuner. Detta ledde till krav på statliga insatser för att utjämna eller minska fattigvårdsbördan och frågan om kommunal skatteutjämning kom att aktualiseras (Andersson, 1995). Det visade sig emellertid svårt att på detta sätt nå ett positivt riksdagsbeslut. En pensionsförsäkring däremot sågs som en möjlighet då det gällde att mildra och utjämna fattigvårdsbördan.

En annan faktor att beakta är finansieringsmöjligheterna. Allt annat lika skulle en pensionsförsäkring i Sverige bli betydligt dyrare än i andra länder p.g.a. den demografiska situationen. Till detta kommer statliga satsningar på försvarsutgifter under åren före första världskriget. En dansk eller engelsk modell, med renodlad skattefinansiering, blev därför svår att acceptera. I Raabs modell hade explicit hänsyn tagits till kostnader och finansiering genom den föreslagna enhetsavgiften, som ju helt enkelt var en skatt. Det fanns emellertid ett stort problem med Raabs föreslagna avgift: den drabbade alldeles särskilt låginkomsttagare. Avgiften var en personlig skatt av det slag som användes i det förindustriella samhället, där naturahushållning förekom och där det inte fanns möjlighet för inkomstdeklaration.

En ny finansieringsmöjlighet kom med inkomstskatten. Som Sverige ekonomiskt utvecklades blev inkomster ett skatteobjekt. År 1902 infördes en statlig progressiv inkomstskatt. Härmed kom också inkomstdeklarationen. Då kunde inkomster och därmed skatter och egenavgifter baserade på inkomst fastställas. Här öppnades alltså en ny finansieringsmöjlighet, som inte fanns med i de tidigare pensionsdiskussionerna. De nya egenavgifterna kan alltså ses som en specialdestinerad skatt och som en del av skattepolitiken. Härigenom nås en viss utjämning av fattigvårdskostnaderna mellan kommunerna. Det blev alltså en tidig form av interkommunal skatteutjämning.

Fattigvårdsfolkets syn på utformningen av en pensionsförsäkring hade framgått under 1906 års fattigvårdskongress. En pensionsförsäkring skulle vara försäkringsmässig och av de då aktuella modellerna var det den tyska, som svarade mot detta villkor. Då ålderdomsförsäkringskommittén presenterat sitt betänkande 1912 star- 
tade fattigvårdsfolket en häftig kampanj mot förslaget (Edebalk, 1996). Måltavlan för kampanjen blev tilläggspensionen. Den stred helt mot deras uppfostringsideologi. Den inkomstprövade tilläggspensionen, menade man, skulle minska arbetsviljan och sparsamheten. De vände sig också med kraft mot att "ovärdiga» skulle få pension. Till den gruppen hörde arbetsovilliga, försumliga familjeförsörjare och andra som visat asocialt beteende. I detta avseende vann man vissa framgångar genom att vissa "värdighetsbestämmelser" infördes i den slutliga lagen vilka bl.a. uteslöt den som förde ett asocialt levnadssätt.

Med 1913 års beslut tillkom i Sverige världens första allmänna pensionsförsäkring. Reformen innebar en rejäl inskränkning av fattigvårdsfolkets domäner. Enligt kommittébetänkandet skulle reformen, beräknat för år 1907, befria 83000 åldringar från fattigvården (Ålderdomsförsäkringskommittén, 1912). Den individuella behovsprövningens tillämpningsområde beskars alltså ordentligt.

\section{Åldringsvården och 1918 års reform}

Fattigvårdslagstiftningskommitténs betänkande avlämnades år 1915. Kommittén formulerade i allt väsentligt sina förslag $i$ enlighet med „Reformlinjer" (Fattigvårdslagstiftningskommitténs betänkanden, 1915). Något annat var knappast att vänta med tanke på fattigvårdfolkets ställning inom kommittén. Det slutliga riksdagsbeslutet 1918 följde i stort kommittéförslagen (Proposition 1918:135, Edebalk, 1991). Genom reformen utvidgades området för obligatorisk fattigvård, besvärsrätt infördes, fattigvårdens husbonde- och målsmansrätt för myndiga togs bort. En tjänst som statlig fattigvårdsinspektör skulle inrättas och rotegång och bortauktionering förbjöds. Ett av de viktigaste syftena med reformen var att åstadkomma en upprustad anstaltsvård. $\mathrm{Nu}$ slogs fast att varje kommun skulle ha anstalt (man använde här oftast benämningen ålderdomshem) och att anstaltsfrågan skulle vara löst inom en tioårsperiod.

Den kommunala åldringsvården skulle bestå av ålderdomshem. Dessa skulle vara till för det man skulle kunna kalla "normalt åldrande» personer. Fattigvårdsfolket hade därför krävt att staten skulle bygga ut sinnessjukvården och att landstingen skulle bli huvudmän för kronikervården. Frågan om landstingens huvudmannaskap ingick i 1918 års reform men blev endast en halv seger. Landstingen skulle bidra till kostnaderna men ålades ingen skyldighet att driva kronikerhem. Vissa kvalitetskrav ställdes på ålderdomshemmen exempelvis att sinnessjuka och kroniker skulle vårdas i särskilda rum eller avdelningar, att äkta makar borde få bo tillsammans och att endast den kunde bli föreståndare som ägde »nödiga förutsättningar för skötande av dylik befattning".

Fattigvårdsreformen var ingen kontroversiell eller "stor" politisk fråga. Det sågs allmänt som nödvändigt att ersätta 1871 års reform med något nytt, mer humant. Det var fattigvårdsfolket som varit pådrivarna. De kunde också påverka verkställigheten genom att G. H. von Koch blev den förste statlige fattigvårdsinspektören. 


\section{Läget omkring 1920}

Redan före, men framförallt efter, 1906 års fattigvårdskongress hade två socialpolitiska ideologier framträtt. Enligt den ena, företrädd främst av fattigvårdsfolket, skulle en humaniserad fattigvård ha ett stort revir inom socialpolitiken och individuella understödsbehov skulle avgöra de socialpolitiska insatserna. Det nya trygghetssystemet, socialförsäkringarna, måste enligt ideologiföreträdarna vara försäkringsmässigt uppbyggda.

Enligt den andra ideologin borde fattigvården, mer eller mindre, elimineras. Denna nya ideologi vann en förkrossande seger i pensionsstriden 1913. Även om den allmänna pensionsförsäkringen hade sina brister och magra ersättningar så blev färdvägen klart utstakad. Det gjordes helt klart att förbättringar skulle komma (Elmér, 1960). Socialförsäkringsidéns triumf framgår också av beslutet om olycksfallsförsäkring (en yrkesskadeförsäkring) 1916 och i tillsättandet av en ny socialförsäkringsutredning 1915, som skulle lägga förslag på en allmän sjukförsäkring och arbetslöshetsförsäkring (Socialförsäkringskommittén, 1919). Några omedelbara positiva effekter av denna utredning visade sig emellertid inte, främst p.g.a. den svåra deflationskris som bröt ut alldeles i början av 1920-talet och en härefter fortsatt hög arbetslöshet.

Den agrara sektorns betydelse för reformerna inom äldrepolitiken är påtaglig. Tillkomsten av socialförsäkringar brukar ofta tillskrivas industrialiseringen, dess sociala följder för främst arbetarklassen samt de nya organisationer och partier som uppkom. Givetvis är industrialiseringen en bakomliggande faktor i den svenska utvecklingen. I den tyska socialförsäkringen på 1880-talet infördes först en sjukförsäkring, som blev det man kan kalla "grundbulten", och härefter kom yrkesskadeförsäkringen och pensionsförsäkringen. Detta kan försäkringsteoretiskt ses som en logisk uppbyggnad. I Sverige började man bygga socialförsäkringssystemet "bakifrån", alltså först med en pensionsförsäkring i stället för en sjukförsäkring. Det märkliga med denna ansats framgår bl.a. av att pensionsförsäkringen innehöll en invaliditetsförsäkring (den tidens förtidspension). Innan en sådan införs borde det, kan man tycka, finnas en allmän sjukförsäkring som tar hand om kortare sjukfall. Sjukförsäkringens organ kan då dels bidra till att förebygga och lindra processer som leder till mer kroniska sjukdomstillstånd dels svara för en "sortering« av sjuka till yrkesskadeförsäkring och invaliditetsförsäkring. Den uppbyggnad "bakifrån" som skedde kan tillskrivas den agrara sektorn betydelse. Det var främst på landsbygden som problemen fanns, men också, i stor utsträckning, väljare och riksdagsmän. Pensionerna syftade bl.a. till att finansiellt hjälpa landsbygdskommunerna. 1918 års reform var i mångt och mycket inriktad mot samma kommuner; det var där som situationen för orkeslösa äldre var som värst.

Under 1910-talet knäsattes två för den framtida svenska socialpolitiken väsentliga socialpolitiska principer. Den första principen var universalism. Den allmänna pensionsförsäkringen innehöll en helt ny syn på sociala rättigheter. Socialpolitiken skulle inte endast inrikta sig på de fattiga utan samtliga medborgare skulle omfat- 
tas. Socialförsäkringsfrågan omfattades av ett stort politiskt intresse och, för att ta ett exempel, i det utskott som år 1916 beredde olycksfallsförsäkringen var högerledaren Arvid Lindman ordförande och Hjalmar Branting vice ordförande. Branting hade dessutom ingått i ålderdomsförsäkringskommittén. Det breda intresset för socialförsäkringsfrågan kontrasterar mot fattigvårdsfrågan.

Den andra principen som slogs fast var kommunernas ansvar för åldringsvården. Beträffande det kommunala huvudmannaskapet över fattigvården känner man igen resonemangen från "Reformlinjer». Det uttrycktes dock visst tvivel under riksdagsbehandlingen 1918 att de små och ekonomiskt svaga kommunerna skulle lyckas reformera sin åldringsvård (Protokoll FK 1918:32 och AK 1918:52). Att kommunerna accepterades som huvudmän kan säkert tolkas ur olika perspektiv. Man kan hävda att den allmänna pensionsförsäkringen, i viss utsträckning, förväntades utjämna fattigvårdsbördan, att en statlig satsning på sinnessjukvård ställdes i utsikt, att landstingen skulle ta över vissa tyngre vårdkostnader samt att kommuner också gavs möjlighet att tillsammans ordna ålderdomshemsfrågan. I övrigt var huvudargumentet för ett kommunalt huvudmannaskap att man ute i kommunerna kände invånarna och utan besvärliga undersökningar kunde bedöma om hjälp behövdes. Kommunalt huvudmannaskap ansågs också skapa incitament till en kostnadsmedveten fattigvård (se också Berge, 1995). Att kommunerna valdes kan också tolkas som att alltför starka ingrepp i kommunernas hävdvunna ställning och självbestämman- derätt ansågs ligga utanför de politiska realiteterna. Det var tydligt känsligt nog att inskränka den kommunala friheten med obligatoriska ålderdomshem, statlig inspektör m.m. Man kan sammanfatta det så att med socialförsäkringsideologin beträddes en helt ny socialpolitisk väg; med ålderdomshemsideologin beträddes ingen ny väg, det var den gamla som förbättrades.

\section{Pensionsfrågan 1920-1948}

Den högkonjunktur som följt på världskriget avlöstes av en lågkonjunktur alldeles i början av 1920-talet. Denna ledde till en ekonomisk depression som blev särskilt allvarlig för Sverige genom att den internationella lågkonjunkturen sammanföll med en inhemsk deflationspolitik. Som värst var det vintern 1922 då arbetslösheten översteg 30 procent enligt fackföreningsstatistiken (Öhman, 1970). Även sedan depressionen hävts kvarstod en hög arbetslöshet under resten av 1920-talet. Följande den tidens krav på en balanserad statsbudget kom den ekonomiska politiken att präglas av besparingskrav. Uttrycket "sträng sparsamhet med allmänna medel« användes frekvent av den borgerliga riksdagsmajoriteten (Håkansson, 1959) och ger en fingervisning om vad politiken gick ut på.

Det skulle dröja decennier innan 1913 års avgiftspension skulle få en godtagbar socialpolitisk effekt. De utgående pensionerna kom därför i allt väsentligt från den inkomstprövade tilläggspensionen. Beloppen var magra och framförallt i städerna tvangs ålderspensionärer komplettera pensionen med fattigvård. År 1928 motionerade socialdemokraterna, med 
Gustav Möller som ledande namn, om att pensionsfrågan skulle utredas (Motion FK 1928: 169). Motivet var i första hand att fattigvården sågs som en "ovärdig» hjälpform för pensionärerna. En utredning tillsattes, vars betänkande (SOU 1934:18) i mångt och mycket kom att ligga till grund för pensionsreformer åren 1935 och 1937.

Det nya i 1935 års pensionsreform var bl.a. att avgiftsdelen (dvs. det man kan kalla det försäkringsmässiga) tonades ner och man kom att använda benämningen folkpensionering (Elmér, 1960). Den tidigare avgiftspensionen omvandlades till en (mycket låg) grundpension. Grundpensionen blev densamma för män och kvinnor och detsamma gällde tilläggspensionen. Principiellt nytt i utredningsförslaget och i regeringens proposition var att tillläggspensionen dyrortsgrupperades, dvs. högre pensioner i städerna och lägre på landsbygden. Motståndet mot dyrortsgrupperingen kom i riksdagen, naturligt nog, främst från bondeförbundet som fick stöd av övriga borgerliga partier. Någon dyrortsgruppering beslutades följaktligen inte men Gustav Möller, som nu blivit socialminister, lovade komma igen med ett förslag om dyrortsgruppering. Så skedde året därpå (Proposition 1936:182). Än en gång blev det avslag, regeringen avgick och i den följande valkampanjen spelade agitationen för dyrortsgrupperade pensioner en framträdande roll. Efter en socialdemokratisk valseger 1936 kom riksdagen att besluta om dyrortsgrupperade pensioner år 1937 (Proposition 1937:15). Resultatet blev en betydande förbättring för städernas pensionärer. Detta, och vissa höjningar under kriget, till trots fick årligen omkring 30 procent av pensionsmottagarna fattigvård under perioden 1939-47 (Elmér, 1960). Andelen var ungefärligen dubbelt så hög $\mathrm{i}$ städerna som på landsbygden.

1920-talets socialpolitik och socialpolitiska diskussioner var i stor utsträckning präglade av den svåra arbetslöshet och de besparingskrav som rådde även efter det att deflationskrisen övervunnits. Så kom den stora depressionen alldeles i början av 1930-talet. Härunder och härefter skedde en socialpolitisk nydaning med satsningar på sysselsättningspolitik, social bostadspolitik, smärre socialförsäkringsreformer och det som kallades befolkningspolitik. Den socialpolitiska utvecklingen under 1930talet var i och för sig inte kvantitativt imponerande men socialpolitiken blev mer vittförgrenad. Detta påverkade fattigvården dels genom att fattigvård tedde sig än mer deklasserande, dels att fattigvårdens ställning inom det totala socialpolitiska systemet aktualiserades. Nu tillsattes, alldeles i början av år 1938, den s.k. socialvårdskommittén, som fick ett brett socialpolitiskt uppdrag. Ordförande blev landshövdingen och den tidigare socialdemokratiske riksdagsledamoten Bernhard Eriksson, som bl.a. varit ledamot i den pensionsutredning som tillsattes 1928.

Socialvårdskommittén verkade under 13 år och publicerade inte mindre än 19 offentliga betänkanden. År 1945 kom kommitténs pensionsbetänkande (SOU 1945:46). Tre alternativ presenterades. Gemensamt för dem var att pensionsbeloppen skulle frigöras från avgiftsbetalningar. Avgiften blev helt enkelt en ren skatt (avgiftsfondering hade upphört redan 1939 som en följd av upprustningen). Gemensamt för de tre för- 
slagen var vidare att pensionsnivån skulle vara så hög att pensionärerna inte skulle behöva kompletteringar från fattigvården. I de två första alternativen var pensionen inkomstprövad, enligt det tredje alternativet skulle pensionen vara en enhetspension, dvs. lika för alla. Inkomstprövad pension motiverades främst av statsfinansiella skäl. Enhetspensionen blev dyrare för statsverket men skulle samtidigt ge en påtaglig administrativ förenkling. Vidare skulle en enhetspension inte negativt påverka incitamenten till arbete och sparande.

En principiellt intressant debatt följde efter det att betänkandet publicerats (Elmér, 1960). Det handlade om huruvida alla, d.v.s. även välbärgade, skulle få pension eftersom detta skulle åsamka statsverket högre utgifter. Socialminister Gustav Möller var en utpräglad företrädare för enhetspensioner och därmed en ledande företrädare för den ersättningsprincip som brukar kallas medborgarrätt. Andra ledande socialdemokratiska regeringsledamöter var till att börja med negativa, främst finansminister Ernst Wigforss. Möllers linje segrade i regeringen men detta först efter det att både högern och bondeförbundet tagit ställning för enhetspensionen. År 1946 antog en i princip enhällig riksdag den nya lagen om folkpensionering (Proposition 1946:220). Pensionen, som skulle utgå till alla som fyllt 67 år, uppgick till 1000 kronor om året för ensamstående och 1600 kronor till äkta makar. Till pensionen kom olika tillägg bl.a. ett inkomstprövat och dyrortsgrupperat bostadstillägg. 1946 års folkpensionsreform var världens första universella socialförsäkring byggd på medborgarrättens grund (Kohl, 1993).

\section{Åldringsvårdsfrågan 1920-48}

Starten för byggandet av de nya ålderdomshemmen blev trög (Edebalk, 1991). Den svåra deflationskrisen i början på 1920-talet och den relativt höga arbetslösheten resten av decenniet skapade rent allmänt en bekymmersam situation för kommunerna. För landsbygden förvärrades situationen genom fallande jordbrukspriser och ekonomiska svårigheter för jordbruket. Riksdagen beslutade om ett par års generellt uppskov med färdigställandet av ålderdomshem och i början av 1930-talet var ålderdomshemsfrågan löst i den meningen att varje kommun hade eget eller del i ett ålderdomshem. Enligt en undersökning 1938 fanns utanför de tre största städerna 1410 ålderdomshem i landet, varav 1302 på landsbygden. Majoriteten av ålderdomshemmen var små. 195 hem hade 10 eller färre platser och 717 hem hade mellan 11 och 20 (SOU 1940:22).

Kvantitativt hade således 1918 års reform varit en framgång. Ett allvarligt problem var dock den s.k. klientelblandningen. Viktiga förutsättningar då reformen beslutades var att sinnessjukvården och kronikervården skulle byggas ut. Så blev emellertid inte fallet, något som i mångt och mycket sammanhängde med det kärva ekonomiska läget under mellankrigstiden. Kronikervårdens problem berodde dessutom på att ingen huvudman fick något konkret åtagande motsvarande det som kommunerna fick beträffande ålderdomshemmen. Och för sinnessjukvården, med staten som huvudman, var platsbristen skriande. I den ovan redovisade undersökningen år 1938 angavs att 2/3 av de boende på ålderdomshem tillhörde 
den tänkta målgruppen. 14 procent av de boende ansågs i behov av sinnessjukvård, ca 5 procent var kroniskt sjuka och i behov av annan vårdform och en något större andel var varaktigt sängliggande. En mindre grupp vårdtagare betecknades som "svårhanterliga eller störande för omgivningen".

Att många ålderdomshem var små förvärrade problemet. Små hem hade inte samma möjlighet som större att inrätta särskilda avdelningar. De små hemmen, och därmed småkommunerna, hade emellertid också andra allvarliga brister. Det var svårt, för att inte säga omöjligt, att rekrytera kompetent personal särskilt $i$ avfolkningsbygder och någon "vård» var det knappast fråga om. Arbetsvillkoren var knappast lockande. Föreståndarinnan måste i princip vara tillgänglig dygnet runt och att vid de små hemmen ordna avlösning eller semester och semestervikarie var problematiskt.

Ålderdomshemmen tillhörde fattigvården och skulle alltså ta hand om fattiga gamla. Mer välsituerade hade alltså i princip inte tillgång till offentlig åldringsvård; de ansågs ha tillgång till privata lösningar (t.ex. hembiträden eller samboende med barn). Möjligheten till privata lösningar försvagades emellertid under mellankrigstiden, bl.a. genom avflyttningen från landsbygden. Vårdbehövande äldre med god ekonomi började söka sig till ålderdomshemmen som självbetalande. De kallades helinackorderingar och för dem gällde, till skillnad från understödstagarna, att de inte drabbades av negativa rättsverkningar (t.ex. förlust av rösträtt). Av de boende på ålderdomshemmen var ca 17 procent helinackorderingar vid slutet av mellankrigstiden (SOU 1946:52).
En annan tendens under mellankrigstiden var byggandet av s.k. pensionärshem. Dessa tillkom som ett komplement till den allmänna pensionsförsäkringen och syftade till att ge äldre en bra bostad till en låg, d.v.s. subventionerad, hyra. Målgruppen var pensionärer, som antingen hade hopplöst omoderna bostäder eller tvangs anlita fattigvården för att klara hyresbetalningarna. Speciellt under 1930-talet växte intresset för pensionärshem i de svenska städerna. Något mer påtagligt intresse för pensionärshem kan däremot inte förmärkas på landsbygden. År 1939 beslutade riksdagen om statsbidrag till uppförandet av pensionärshem (Proposition 1939:177). Pensionärshemmen representerade ett kategoriboende utan institutionskaraktär och de hade inte de rättsverkningar, som var förknippade med ålderdomshemmen. Kritiken mot pensionärshemmen kom främst från Fattigvårdsförbundet. "Deras" ålderdomshem skulle ju nu te sig mindre tilltalande.

Den fortgående urbaniseringen under mellankrigstiden förvärrade ålderdomshemmens problem. I början av perioden bodde majoriteten av befolkningen på den egentliga landsbygden; år 1940 var landsbygdsbefolkningen i klar minoritet. En effekt av detta blev att antalet småkommuner ökade och år 1940 hade närmare hälften av landets kommuner färre än 1000 invånare (SOU 1942:56). Det gjordes olika framstötar under 1930-talet för att lösa småkommunsfrågan men det visade sig vara känsligt att ge sig på den kommunala självstyrelsen. Krav på ny kommunindelning byggde inte bara på hänsyn till åldringsvården. Det gällde exempelvis också 
skolan och polisväsendet. Kraven på större lokala enheter för åldringsvården m.m. var en viktig faktor bakom tillsättandet av socialvårdskommittén kring årsskiftet 1937/38.

Socialvårdskommittén menade att den dåvarande kommunala indelningen överlevt sig själv och att det mest rationella vore en kommunal nyindelning (SOU 1942:56). En sådan reform ansågs emellertid innebära ett omfattande och tidskrävande utredande, vilket skulle fördröja reformerandet av åldringsvården. Därför föreslogs i stället bildandet av särskilda specialkommuner s.k. "socialvårdskommuner", vilka borde ha 3-4000 invånare. Detta befolkningsunderlag antogs svara mot ett ålderdomshem med minst 25 platser. Socialminister Gustav Möller tillsatte emellertid snabbt en ny utredning som publicerade ett betänkande om en ny kommunal indelning 1945 (SOU 1945:38). Riksdagen fattade ett positivt beslut året därpå och den nya kommunindelningen kom att gälla från 1952. Detta blev en viktig förutsättning för en kommande reformering av åldringsvården. En annan viktig förutsättning var riksdagens beslut 1946 om folkpension.

Socialvårdskommittén publicerade 1946 ett betänkande om ålderdomshem (SOU 1946:52). Anledningen till att ålderdomshemsfrågan särbehandlades sammanhängde med att en reform på detta område var betingad av utbyggnaden av andra vårdformer. En utbyggnad av vårdformerna för, som det då hette, sinnessjuka, sinnesslöa och kroniskt sjuka skulle givetvis ta avsevärd tid. Det var därför angeläget att statsmakterna snarast drog upp riktlinjer. Genom att den nya folkpensionen utgick enligt den s.k. minimistandardprincipen skulle i princip ingen pensionär bli understödstagare $\mathrm{i}$ den gamla fattigvårdsmeningen. Ålderdomshemmen borde därför, enligt kommittén, upphöra att vara fattigvårdsanstalter. Hemmen skulle vara öppna för alla vårdbehövande äldre oavsett privatekonomisk ställning och i stället för wunderstödstagare» skulle hemmen bebos av »helinackorderingsgäster».

Socialvårdskommittén var kritisk till pensionärshemmen. Krya gamlingar borde bo i sin invanda miljö, och inte på pensionärshem, och de som behövde vård borde bo på ålderdomshem. Kommittén var dock medveten om att pensionärshem måste finnas under överskådlig tid eftersom många åldringar bodde $i$ helt undermåliga lägenheter. Det måste dock finnas en tydlig gräns: åldringsvård skulle enbart finnas på ålderdomshem.

På de föreslagna ålderdomshemmen skulle merparten av rummen vara enkelrum. Det skulle också vara möjligt att ta med egna möbler. Dock var en förutsättning watt de gamlas möbler och persedlar blir föremål för betryggande desinfektionsåtgärder" (SOU 1946:52, sid 30). Detta kan ses som en illustration till de miserabla boendeförhållanden som många äldre levde under. En annan viktig kvalitetsförutsättning gällde storleken på ålderdomshemmen. Antalet platser borde inte understiga 25. Därigenom skulle arbetsförhållandena kunna bli mer attraktiva och positiva för personalrekryteringen.

Enligt socialvårdskommittén förelåg ett latent behov av ålderdomshemsvård som skulle göra sig gällande så snart de moderna hemmen skapats. Ett stort utbyggnads- 
program aktualiserades inte minst med tanke på det växande antalet åldringar. För att stimulera utbyggnaden borde därför statsbidrag utgå till byggkostnaderna. Platsbehovet uppskattades till ungefärligen tio procent av åldringarna över 65 år, dvs. till mer än 70000 platser. Detta skulle innebära nästan en tredubbling av de dåvarande platserna vid ålderdomshem.

På basis av kommittérapporten avlämnade Gustav Möller en proposition till riksdagen år 1947 (Proposition 1947:243). De nya riktlinjerna antogs av en enhällig riksdag. Ett effektuerande av riktlinjerna skulle få bort fattigvårdskaraktären på hemmen. Kvaliteten skulle vara så hög att hemmen blev attraktiva för alla och kvantiteten så stor att alla vårdbehövande skulle få plats. En viktig roll spelar avgiften. Genom att betala en avgift kunde den gamle betraktas som en "gäst» i ungefär samma mening som på ett pensionat. De gamlas status skulle höjas samtidigt som avgifterna blev en finansieringskälla för kommunerna. Avgifterna borde vara lika för alla, oberoende av inkomst- och förmögenhetsförhållanden.

1947 års riktlinjer representerade institutionstankens triumf inomåldringsvården. Några andra politiska ställningstaganden avvaktades. En utredning om statsbidragen till ålderdomshemmen blev färdig 1950 och förordade likartade statsbidrag till ålderdomshem och pensionärshem (SOU 1950:22). Riksdagen godkände 1950 en generalplan för sinnessjukvården (Proposition 1950:113) och 1951 fick landstingen huvudmannaskapet för vården av kroniskt sjuka (Proposition 1951:20). Dessa beslut låg inom ramen för 1947 års riktlinjer så nu var det bara för kommunerna att bygga moderna ålderdomshem.

Fattigvårdsfolket, och därmed CSA-kretsen, hade varit pådrivande inför 1918 års fattigvårdsreform. Bakom tillkomsten av 1947 års riktlinjer finner vi fattigvårdsfolkets efterträdare och ideologiska arvtagare, det vi kan kalla socialvårdsetablissemanget (Edebalk, 1991). Kärntruppen bestod av fyra personer: Statens fattigvårdsinspektör Ali Berggren, socialstyrelsechefen Ernst Bexelius, förre direktören i Fattigvårdsförbundet och förre chefen för socialstyrelsen Karl J. Höjer samt fattigvårdsdirektören Otto Wangson, som tidigare, direkt efter von Koch, varit statens fattigvårdinspektör. Dessa kan sägas ha varit »ideologiproducenter" vad gäller 1947 års riktlinjer och de tre senare var också ledamöter $\mathrm{i}$ socialvårdskommittén och Höjer var den i kommittén som varit huvudansvarig för utarbetandet av betänkandet. Efterträdarna innehade befattningar och representerade organisationer som kan kopplas till CSA. I likhet med fattigvårdsfolket var de envisa, engagerade och pådrivande och de verkade på olika sätt som opinionsbildare. Ännu en likhet med fattigvårdsfolket var att de var socialt väletablerade urbana personer, som ville förbättra förhållandena för de gamla, särskilt på landsbygden. De var goda paternalister, som "visste« vad de gamla hade för behov. De »visste« att åldringarna skulle uppskatta ålderdomshemmet. Ernst Bexelius, för att ta ett exempel, yttrade i ett tal 1947 att då rålderdomshemmen blivit vad de skola bli, inackorderingshem med stor trivsel, kommer de gamla att längta dit för att få den personliga omvårdnad, som där kommer att bjudas» (Bexelius, 1947 sid. 501). 


\section{Åldringarna och folkhemmet}

Riksdagsbesluten 1946 (folkpensionen) och 1947 (ålderdomshemmen) låg i linje med socialminister Gustav Möllers socialpolitiska ideologi (Edebalk, 1996). Alla medborgare skulle omfattas och de socialpolitiska insatserna skulle vara odifferentierade, dvs. lika för alla, givet behovsbilden, och oberoende av den enskildes ekonomiska förutsättningar. I allt väsentligt skulle åtgärder finansieras med allmänna skatter. Detta gällde inte enbart inom åldringspolitiken. Sjukpenningen, för att ta ett annat exempel, skulle vara en enhetsersättning och alltså inte relaterad till den enskildes inkomstförlust vid sjukdom. Möllers politik syftade till att utrota fattigdom; han använde uttrycket "frihet från nöd». Titeln på en Möllerskrift från 1948 är belysande: "Från Fattighus-Sverige till Social-Sverige" (Möller, 1948).

Det universella inslaget genomsyrade Gustav Möllers socialpolitik. Möller fullbordade i detta avseende en idé som för åldringspolitiken manifesterades redan i 1913 års allmänna pensionsförsäkring. Den universella idén år 1913 var fotad i Sveriges agrara struktur. Det är väl så påtagligt att den skattefinansierade enhetspension, som trädde i kraft 1948, särskilt gynnade landsbygdsbefolkningen fördelningsmässigt (Olofsson, 1993). Att skattefinansierade enhetspensioner tilltalar landsbygdsintressen framgår också av erfarenheter utomlands (se t.ex. Kangas, 1989). Folkpensionen i Sverige tilltalade emellertid också mer urbana intressen representerade exempelvis av organisationerna LO, TCO och SAF. För dessa handlade det bl.a. om relationen till tjänstepensionering (Harrysson, 2000). En enhetspension, till skillnad från en inkomstprövad pension, skulle utgå oberoende av företagsfinansierade pensioner och skulle vara lättare att samordna med tjänstepensioner.

Åldringsvård var synonymt med ålderdomshem. Detta var en självklarhet för fattigvårdsfolket och socialvårdsetablissemanget. Då processen väl kom i gång, och här kan 1906 års fattigvårdskongress ses som ett startdatum, sågs inget alternativ till ålderdomshemmet som den offentliga vårdformen. Fattiga åldringar hade då helt undermåliga bostäder, om de ens hade bostad, och "öppen" åldringsvård innehöll bl.a. kringgång, utackordering och auktionering. Ålderdomshemsideologin levde vidare i föreställningsvärlden. Detta framgår av 1946 års betänkande, remissyttranden och riksdagsbehandlingen (Edebalk, 1991). Ålderdomshemmet var ett så självklart alternativ att det inte ens behövde motiveras. Då det gällde motiveringar handlade det om att höja ålderdomshemmens kvalitet t.ex. att eliminera klientelblandningen och att få bort de små hemmen. Ålderdomshemsfrågan var framför allt en landsbygdsfråga. Detta gäller såväl kvalitet som kvantitet. I städerna fanns vid slutet av 1940-talet mindre än 30 procent av ålderdomshemsplatserna (SOU 1955:34).

Man kan emellertid fråga sig varför 1947 års riktlinjer endast omfattar ålderdomshem och inte alls hemhjälp. Det fördes i och för sig ingen explicit diskussion härom. Det krävs emellertid inte mycket fantasi för att förstå varför så var fallet. Ålderdomshemsideologin var starkt förankrad i det agrara Sverige. Landsbygdens avfolkning var snabb 
under mellankrigstiden och speciellt snabb från mitten av 1930-talet. Effekten blev ett wåldringsöverskottu och samtidigt ett "kvinnounderskott». Det var emellertid inte bara så att de flesta åldringarna bodde på landsbygden; många bostäder där var hopplöst omoderna och saknade vatten, avlopp och elektricitet. Detta hade socialvårdskommittén påvisat (SOU 1945:23). Att med dessa förutsättningar rekrytera vårdbiträden för att arbeta inom hemhjälp var säkerligen omöjligt. Det rörde sig om stora avstånd (och bilismen var outvecklad) och mycket praktiskt arbete i ofta undermåliga bostäder. Det skulle helt enkelt krävas horder av vårdbiträden. De ungdomskullar från 1930-talet som väntades ut på arbetsmarknaden var små; det var ju en följd av de låga födelsetal som makarna Myrdal oroat sig för. Med det goda arbetsmarknadsläge som rådde efter andra världskriget var konkurrensen om de nytillträdande på arbetsmarknaden hård och hemhjälpsverksamhet på landsbygden skulle här stå sig slätt. Arbetsmiljön skulle inte kunna konkurrera med den som erbjöds i affärer och kontor i tätorterna. Så hemhjälp diskuterades överhuvudtaget inte.

Med 1947 års ålderdomshem förhöll det sig annorlunda. De skulle vara lokalmässigt och utrustningsmässigt moderna och, jämfört med de gamla, förhållandevis stora. Följaktligen skulle de kunna ge en attraktiv arbetsmiljö och attraktiva arbetsscheman. Detta skulle underlätta rekryteringen. De nya ålderdomshemmen skulle alltså bli bättre både för de gamla och för vårdbiträdena och relativt få vårdbiträden skulle då kunna hjälpa relativt många åldringar. Detta var Folkhemmets åldringsvård, öppen för alla behövande och befriad från fattigvårdsstämpeln.

Den socialpolitik som drevs åren närmast efter andra världskriget kan vi kalla för »Folkhemspolitik». Politiken skulle vara universell med odifferentierade åtgärder. Åldringarna skulle erhålla lika mycket i pension oberoende av sin ekonomiska situation och vårdbehoven skulle de nya ålderdomshemmen ta hand om. Det är, som Sven E Olsson skriver på ett ställe, inte reformerna från fyrtiotalets mitt som är det viktigaste upphovet till Sveriges rykte som modellstat på välfärdspolitikens område (Olsson, 1990). Det är nämligen först på 1950-talet som socialpolitiken blir mer differentierad. Då utvecklas det man brukar kalla »Välfärdsstaten».

Folkpensionen gav ett avstamp för en obligatorisk tjänstepension baserad på inkomstbortfallsprincipen, ATP. Det är signifikativt att, vid den folkomröstning som föregick 1959 års ATP-beslut, landsbygdsintressenas linje innebar en höjning av folkpensionen plus frivillig påbyggnad. Det var också detta alternativ som av de tre möjliga fick minst antal röster. Inkomstbortfallsprincipen segrade till slut också i den allmänna sjukförsäkring som trädde i kraft 1955.

Inom åldringsvården skedde åren omkring 1950 en ideologisk drabbning mellan författaren Ivar Lo-Johansson och socialvårdsetablissemanget (Gaunt, 1995, Jönsson, 2001). Detta var första gången som åldringsvården blev föremål för en öppen debatt och den andra ideologiska drabbningen för fattigvårdsfolket och deras arvtagare. Resultatet blev, liksom inför 1913 års pensionsbeslut, ett svidande 
nederlag och en seger för Lo-Johanssons idé "hemvård i stället för vårdhem». Hemhjälpen började utvecklas med start 1950. Hemhjälpen var från början en urban företeelse med andra förutsättningar än de socialvårdsetablissemanget utgått från. Folkpensionen reducerade ålderdomshemmens försörjningsfunktion. Bättre och modernare bostäder, speciellt i tätorter, gjorde det möjligt för åldringar att bo kvar hemma, och kunde representera en hygglig arbetsmiljö för vårdbiträden. Och hur kunde man nu i början av 1950-talet rekrytera vårdbiträden? Svaret ligger väsentligen i modernare och mer lättskötta bostäder och hushållsteknologiska framsteg. Detta gav förutsättningar för hemmafruar att under en del av dagen engagera sig inom äldreomsorgen och en stor dold arbetskraftsreserv avslöjades. Hemhjälpen kom att expandera kraftigt och till skillnad från ålderdomshemmet var den inte fattigvårdsbelastad. Företrädarna för 1947 års riktlinjer hade inte kunnat förutse de nya förutsättningarna. Ej heller hade de en tanke på att folks obehagliga minnen från fattigvårdstiden skulle belasta ålderdomshemmen långt in i framtiden.

Socialpolitiken är, givetvis, inte statisk. Under den period vi här behandlat kunde Sveriges åldringar se hur idéerna om Folkhemmet höll på att förverkligas. För åldringarnas vidkommande var politikens utformning i mångt och mycket agrarbetingad. Att urbana hänsyn och intressen växer i betydelse framgår bl.a. av striden om dyrortsgruppering av pensionerna och statsbidragen till pensionärshem på 1930talet (se t.ex. Åmark, 1999). Spänningen mellan det urbana och det agrara, mellan det expansiva och det tillbakagående, skärps. Det är bl.a. i detta spänningsfält som 1940-talets socialpolitik befann sig. På 1950-talet kom de urbana intressena att allt mer dominera socialpolitikens utformning. Hemhjälp för åldringar och inkomstbortfallsprincipens definitiva genombrott är goda exempel.

\section{Referenser}

Andersson, Lars (1995) Kommunalskattefrågan under mellankrigstiden. Skatterättvisa $i$ och mellan kommuner. Lund: Lund University Press.

Baldwin, Peter (1990) The politics of Social Solidarity. Class Basis of the European Welfare State 1875-1975. Cambridge: Cambridge University Press.

Berge, Anders (1995) Medborgarrätt och egenansvar. De sociala försäkringarna i Sverige 19011935. Lund: Arkiv.

Bexelius, Ernst (1947) "Våra ålderdomshem». Landskommunernas tidskrift, 1947:11.

Edebalk, Per Gunnar (1991) Drömmen om ålder- domshemmet. Åldringsvård och socialpolitik 1900-1952. Lund: Meddelande från Socialhögskolan 1991:5.

Edebalk, Per Gunnar (1996) Välfärdsstaten träder fram. Svensk socialförsäkring 1884-1955. Lund: Arkiv.

Elmér, Åke (1960) Folkpensioneringen i Sverige. Lund: Gleerups.

Fattigvårdslagstiftningskommitténs betänkanden (1915) II Fattigvårdslagstiftningen. Stockholm. Gaunt, David (1995) „Ivar Lo, de radikala pensionärerna och striden mot ålderdomshemmen 1949«. Socialvetenskaplig tidskrift 1995: 4.

Harrysson, Lars (2000) Arbetsgivare och pensioner. 
Industriarbetsgivarna och tjänstepensioneringen i Sverige 1900-1948. Lund: Värpinge Ord \& Text.

Heclo, Hugh (1974) Modern Social Politics in Britain and Sweden. From Relief to Income maintenance. New Haven and London: Yale University Press.

Håkansson, Sven-Olof (utg) (1959) Svenska valprogram 1900 -1952. Göteborg: Göteborgs universitet, Statsvetenskapliga institutionen.

Jönsson, Håkan (2001) Det moderna åldrandet. Pensionärsorganisationernas bilder av äldre 1941-1995. Lund: Socialhögskolan, Lund Dissertations in Social Work 2.

Kangas, Olli (1989) Politik och ekonomi i pensionsförsäkringen. Det finska pensionssystemet $i$ ett jämförande perspektiv. Stockholm: Institutet för social forskning.

Kohl, Jürgen (1993) »Minimum Standards in Old Age Security and the Problem of Poverty in Old Age». Atkinson A.B. \& Rein M. (eds), Age, Work and Social Security. New York: St Martin's Press.

Lundquist, Lennart (1997), Fattigvårdsfolket. Ett nätverk i den sociala frågan 1900-1920. Lund: Lund University Press.

Möller, Gustav (1948) Från Fattighus-Sverige till Social-Sverige. Stockholm: Tiden.

Olofsson, Gunnar (1993) „Det svenska pensionssystemet 1913-1993: historia, struktur och konflikter" Arkiv för studier i arbetarrörelsens historia nr 58-59

Olsson, Sven E. (1990) Social Policy and Welfare state in Sweden. Lund: Arkiv.

Orloff, Ann Shola (1993) The Politics of Pensions. A Comparative Analysis of Britain, Canada and the United States 1880-1940. London: The University of Wisconsin Press.

Palme, Joakim (1990) Pension Rights in Welfare Capitalism. Stockholm: Swedish Institute for Social research.

Palmstierna, Erik (utg) (1907) Berättelse öfver förhandlingarna vid Kongresen för fattigvaird och folkförsäkring i Stockholm den 4, 5 och 6 oktober 1906. Stockholm.

Reformlinjer för Svensk Fattigvårdslagstiftning af Centralförbundets för Socialt Arbete Fat tigvårdskommitté 1907. Serie: Fattigvård och Folkförsäkring. Stockholm: Ekmans förlagsexpedition.

Riksdagens protokoll jämte bihang.

Salminen, Kari (1993) Pension Schemes in the Making. A Comparative Study of the Scandinavian Countries. Helsinki: The Central Pension Security Institute.

Sjögren, Mikael (1997) Fattigvård och folkuppfostran. Liberal fattiguårdspolitik 1903-1918. Stockholm: Carlssons förlag.

Sköld, Lars \& Halvarson, Arne (1966) »Riksdagens sociala sammansättning under 100 år". Samhälle och riksdag. Stockholm: Almqvist \& Wiksell.

Socialförsäkringskommitten (1919) Betänkande och förslag angående allmän sjukförsäkring. Stockholm.

SOU 1934:18 Betänkande med förslag rörande revision av den allmänna pensionsförsäkringen

SOU 1938:15 Betänkande angående »landsbygdens avfolkning"

SOU 1940:22 Statistisk undersökning angående kommunernas ålderdomshem

SOU 1942:56 Utredning och förslag angående socialvårdens organisation $m \mathrm{~m}$

SOU 1945:23 Statistisk undersökning angående folkpensionärernas bostadsförhällanden $m \mathrm{~m}$

SOU 1945:38 Riktlinjer för en revision av rikets indelning iborgerliga primärkommuner

SOU 1945:46 Utredning och förslag angående lag omfolkpensionering

SOU 1945:53 Statistiska undersökningar kring befolkningsfrågan

SOU 1946:52 Utredning och förslag angående alderdomshem $m \mathrm{~m}$

SOU 1950:22 Statsbidrag för ålderdomshem

SOU 1955:34 Arbetskraftsbehovet inom offentlig verksamhet

Toft, Christian (1996) "The German Pension Debate, Historical Context and Current Direction". Debatte, 2:95-115.

Ålderdomsförsäkringskommittén I (1912) Betän kande och förslag angående allmän pensionsförsäkring. Stockholm. 
Åmark, Klas (1999) „Inkomsttrygghet i Norge och Sverige. Klass, arbetarrörelse och välfärdspolitik 1930-1970«. Arkiv för studier i arbetarrörel- sens historia, $\mathrm{nr}$ 77-78.

Öhman, Berndt (1970) Svensk arbetsmarknadspo-

litik 1900-1947. Stockholm: Prisma.

\section{Summary}

\section{Old age pension and care of the elderly- On Swedish social policy 1903-1950}

Around 1900 the only public measure of social policy for old people in Sweden was municipal poor relief. Half a century later, old people were entitled to a pension, and old people's homes had been separated from poor relief. Attempts to explain the development of social policy can apply different perspectives. We concentrate here on the agrarian sector. Before the First World War, 70 per cent of the population lived in the countryside. Farmers had a strong political influence, and in the election campaign of 1911, when universal male suffrage had been introduced, the political parties tried to win rural voters. An often ignored factor is that Sweden had the oldest population in the known world, relatively speaking; the proportion of people aged over 65 was roughly twice as large as in England or Germany. Many old and infirm people had to resort to the humiliation of letting poor relief provide for them, and rural municipalities were afflicted by high expenses for poor relief.

The problems and political influence of the agrarian sector, together with the rapid industrialization, were important factors behind the general pension insurance of 1913, which was the first universal social insurance in the world. This eased the burden of municipal poor relief. It was fol- lowed by a new Poor Law of 1918, according to which the municipalities were obliged to have old people's homes for old individuals who were poor and in need of care. By the end of the First World War, two principles had been established: social insurance was to be universal and care of the elderly was to be a municipal concern.

The continued industrialization and urbanization led to an "overpopulation" of old people in the countryside. The overwhelming majority of the old people's homes built after the reform of 1918 were in rural municipalities. These homes were often very small, housing a mixture of people with different social problems. There was heavy criticism of the old people's homes run by poor relief. Just after the Second World War it was decided to introduce taxfinanced standard pensions and to separate old people's homes from poor relief. In many ways these decisions were influenced by conditions in the countryside. It was not these reforms that gave Sweden its reputation as a "welfare state model». That did not happen until the 1950s, when home help for old people and a general earnings-related supplementary pension were introduced. In this new social policy, urban considerations and interests acquired a dominant influence. 